\title{
Keputusan Pembelian Konsumen Fitness Center Di Masa Pandemi COVID 19
}

Buying Decision

and COVID 19

Pandemic

\author{
Yulia Nurendah, Rachel Christina \\ ${ }^{1}$ Program Studi Manajemen Pemasaran, Institut Bisnis dan Informatika Kesatuan \\ ${ }^{2}$ Program Studi Manajemen, Institut Bisnis dan Informatika Kesatuan \\ Email : lia_niceone@yahoo.com
}

\begin{abstract}
With the increase in public awareness of sports, it encourages many business opportunities in the sports field. One of them is the fitness center business. This study aims to: 1) to determine the effect of service quality on purchasing decisions on Celebrity Fitness products, 2) to determine the effect of facilities on purchasing decisions on Celebrity Fitness products, 3) to determine the effect of brand trust on purchasing decisions on Celebrity Fitness products, 4) to determine the effect of service quality, facilities, brand trust on purchasing decisions on Celebrity Fitness products. This study took objects (respondents) in Botani Square, Bogor city. Data were analyzed by SPSS (Reliability Test, Validity Test, Classical Assumption Test, Normality Test, Multicolonierity Test, Heteroscedasticity Test, Multiple Regression Analysis, Correlation Analysis, Coefficient of Determination, Statistical Hypothesis Test, Persial Test (t test), Simultaneous Significance Test (Test F)). The results of the analysis are as follows: 1) service quality has a positive effect on purchasing decisions, 2) facilities have a positive effect on purchasing decisions, 3) brand trust has a positive effect on purchasing decisions, 4) service quality, facilities, brand trust have a positive and significant effect on purchasing decisions
\end{abstract}

Keywords: Brand Trust, Facilities, Service Quality, Purchasing Decisions
Submitted:
FEBRUARI 2021

Accepted: APRIL 2021

\begin{abstract}
ABSTRAK
Dengan meningkatnya kepedulian masyarakat terhadap olah raga maka hal tersebut mendorong banyak peluang bisnis di bidang olah raga. Salah satunya adalah bisnis fitness center. Penelitian ini bertujuan untuk : 1) untuk mengetahui pengaruh kualitas pelayanan terhadap keputusan pembelian pada produk Celebrity Fitness, 2) untuk mengetahui pengaruh fasilitas terhadap keputusan pembelian pada produk Celebrity Fitness, 3) untuk mengetahui pengaruh brand trust terhadap keputusan pembelian pada produk Celebrity Fitness, 4) untuk mengetahui pengaruh kualitas pelayanan, fasilitas, brand trust terhadap keputusan pembelian pada produk Celebrity Fitness. Penelitian ini mengambil objek (responden) yang ada di Botani Square kota Bogor. Data dianalisis dengan SPSS (Uji Reliabilitas, Uji Validitas, Uji Asumsi Klasik, Uji Normalitas, Uji Multikolonieritas, Uji Heterokedastisitas, Analisis Regresi Berganda, Analisis Korelasi, Koefisien Determinasi, Uji Hipotesis Statistik, Uji Persial (Uji t), Uji Signifikansi Simultan (Uji F)). Hasil analisis sebagai berikut : 1) kualitas pelayanan berpengaruh positif terhadap keputusan pembelian, 2) fasilitas berpengaruh positif terhadap keputusan pembelian, 3) brand trust berpengaruh positif terhadap keputusan pembelian, 4) kualitas pelayanan, fasilitas, brand trust berpengaruh positif dan signifikan terhadap keputusan pembelian
\end{abstract}

Kata Kunci: Brand Trust, Fasilitas, Kualitas Pelayanan, Keputusan Pembelian 
Buying Decision and COVID 19

Pandemic

\section{PENDAHULUAN}

Masyarakat mulai peduli akan kesehatan dengan mengikuti aktivitas fisik (olah raga). Dengan meningkatnya kepedulian masyarakat terhadap olah raga maka hal tersebut mendorong banyak peluang bisnis di bidang olah raga. Salah satunya adalah bisnis fitness center. Market share untuk fitness center sebagaimana yang terlihat pada Gambar 1

\section{Market Share Fitness Center 2013}

\section{8}

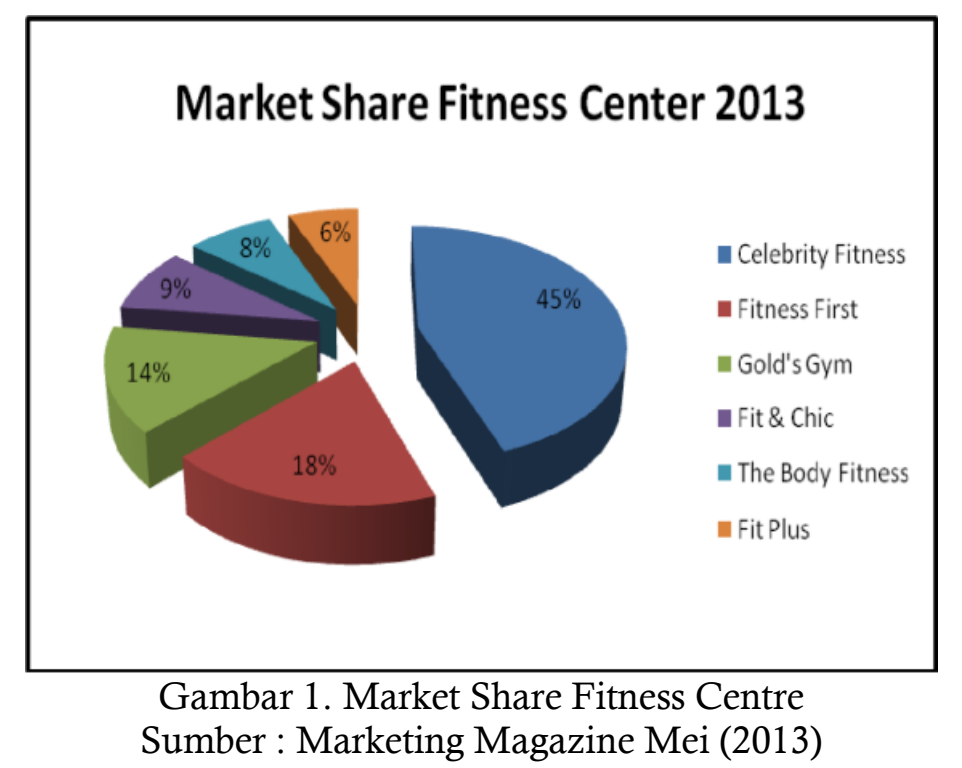

Berdasarkan Gambar 1 di atas, dapat diketahui bahwa meningkatnya pertumbuhan dan perkembangan industri fitness center mengakibatkan tingginya tingkat persaingan antar perusahaan semakin ketat. Banyak faktor yang mempengaruhi konsumen dalam menentukan tempat fitness yang ingin dikunjungi. Diantaranya faktor kualitas layanan, kelengkapan fasilitas berolah raga yang sesuai Faktor yang kedua adalah dalam pemilihan merek dengan tingkat pemilihan merek celebrity fitness karena dilihat sebagai pencitraan terbaik. Hal ketiga yaitu pemilihan saluran distribusi yang dilihat dari kestrategisan dan aksesibilitas menuju tempat kebugaran tersebut. Selanjutnya adalah faktor waktu pembelian sebelum menjadi pelanggan yang dilihat dari segi kebutuhan dan pada waktu ada atau tidaknya promosi atau diskon. Yang kelima adalah jumlah pembelian berdasarkan frekuensi olahraga dalam seminggu atau durasi berolah raga (dalam jam) ditempat kebugaran tersebut. Yang keenam, metode dilihat dari kemudahan pembayaran dan berbagai cara melakukan pembayaran menggunakan kartu kredit atau debit untuk menjadi sarana pembayaran rutin setiap bulan.

Menurut Sampara (2011) pelayanan adalah suatu kegiatan atau urutan kegiatan yang terjadi dalam interaksi langsung antar seseorang dengan orang lain atau mesin secara fisik dan menyediakan kepuasan pelanggan. Menurut Kotler (2012) kualitas pelayanan diartikan sebagai keseluruhan ciri dari barang dan jasa yang mempengaruhi pada kemampuannya untuk memenuhi kebutuhan pelanggan yang dinyatakan maupun tidak dinyatakan.

Menurut Tjiptono (2014), fasilitas merupakan sumber daya fisik yang harus ada sebelum suatu jasa ditawarkan kepada konsumen. Menurut Kotler (2009) merek adalah simbol, tanda, rancangan ataupun sebuah kombinasi dari tiga hal tersebut yang ditujukan sebagai identitas dari beberapa penjual untuk kemudian dijadikan sebagai pembeda dengan pesaing yang ada di pasaran. Menurut Murthy dalam Kertajaya, (2009:11), dari sudut pandang perusahaan, brand trust adalah merek yang berhasil menciptakan brand experience yang berkesan dalam diri konsumen yang berkelanjutan dalam jangka panjang, berdasarkan integritas, kejujuran dan kesantunan brand tersebut.

Perilaku konsumen adalah studi tentang bagaimana individu, kelompok, dan organisasi memilih, membeli, menggunakan, dan bagaimana barang, jasa, ide, atau pengalaman untuk memuaskan kebutuhan dan keinginan mereka (Kotler 2012). 
Tujuan penelitian ini adalah sebagai berikut

1. Untuk mengetahui pengaruh kualitas pelayanan terhadap keputusan pembelian

2. Untuk mengetahui pengaruh fasilitas terhadap keputusan pembelian

3. Untuk mengetahui pengaruh brand trust terhadap keputusan pembelian

4. Untuk mengetahui pengaruh kualitas pelayanan, fasilitas dan brand trustsecara bersama-sama terhadap keputusan pembelian

\section{METODE}

Lokasi Penelitian di Botani Square kota Bogor yang menggunakan Celebrity Fitness. Waktu Penelitian Penelitian ini bulan Juli - Desember 2020. Metode Pengumpulan Data dilakukan dengan Wawancara (interview, Study literatu, dan Kuesioner. Metode Analisis Data dengan menggunakan SPSS untuk menguji : Uji Reliabilitas, Uji Validitas, Uji Asumsi Klasik, Uji Normalitas, Uji Multikolonieritas, Uji Heterokedastisitas, Analisis Regresi Berganda, Analisis Korelasi, Koefisien Determinasi $\left(R^{2}\right)$, Uji Hipotesis Statistik, Uji Persial (Uji t), Uji Signifikansi Simultan (Uji F)

Hipotesis Statistik

1. Hipotesis statistik

a. H0: $\beta 1=0$, kualitas pelayanan tidak mempunyai pengaruh positif dengan signifikan terhadap keputusan pembelian.

b. $H 1: \beta 1 \neq 0$, kualitas pelayanan mempunyai pengaruh positif dengan pengambilan keputusan pembelian.

2. Hipotesis statistik

a. H0: $\beta 2=0$, fasilitas tidak mempunyai pengaruh positif dan signifikan terhadap keputusan pembelian.

b. H2: $\beta 2 \neq 0$, fasilitas diri mempunyai pengaruh positif dengan pengambilan keputusan pembelian.

3. Hipotesis statistik

a. $\mathrm{H} 0: \beta 3=0$, brand trust tidak mempunyai pengaruh positif dan signifikan terhadap keputusan pembelian.

b. H3: $\beta 3 \neq 0$, brand trust mempunyai pengaruh positif dengan pengambilan keputusan pembelian.

4. Hipotesis statistik

a. H0: $\beta 1=\beta 2=\beta 3=0$, Kualitas pelayanan, Fasilitas, dan Brand Trust tidak mempunyai pengaruh positif dengan pengambilan keputusan pembelian.

b. H1: $\beta 1=\beta 2=\beta 3=0$, Kualitas Pelayanan, Fasilitas, dan Brand Trust mempunyai pengaruh positif dengan pengambilan keputusan pembelian

\section{HASIL DAN PEMBAHASAN}

\section{Pengaruh Kualitas Pelayanan (X1) Terhadap Keputusan Pembelian}

Berdasarkan tabel $\mathrm{t}$ diperoleh nilai $\mathrm{T}$ hitung sebesar 1,411 dan $\mathrm{T}$ tabel 1,65 dengan demikian maka $t_{\text {hitung }}$ lebih besar dari pada $t_{\text {tabel }}$ atau $(1,411>1,65)$, H0 ditolak dan H1 diterima. Dengan demikian hipotesis penelitian pertama diterima, berarti ada pengaruh yang positif dan signifikan anatara kualitas pelayanan (X1) dengan keputusan pembelian (Y).

\section{Pengaruh Fasilitas (X2) Terhadap Keputusan Pembelian}

Berdasarkan tabel $\mathrm{t}$ diperoleh nilai $\mathrm{T}$ hitung sebesar 1,397 dan $\mathrm{T}$ tabel 1,65 dengan demikian maka T hitung lebih besar dari pada T tabel atau (1,397>1,65), H0 ditolak dan $\mathrm{H} 2$ diterima. Dengan demikian hipotesis penelitian kedua diterima, berarti ada pengaruh yang positif dan signifikan antara fasilitas (X2) dengan keputusan pembelian (Y).

\section{Pengaruh Brand Trust (X3) Terhadap Keputusan Pembelian}

tabel $\mathrm{t}$ diperoleh nilai $\mathrm{T}$ hitung sebesar 2,565 dan $\mathrm{T}$ tabel 1,65 dengan demikian maka $\mathrm{T}$ hitung lebih besar dari pada $\mathrm{T}$ tabel atau $(2,565>1,65)$, H0 ditolak dan $\mathrm{H} 1$ diterima. Dengan demikian hipotesis penelitian pertama diterima, berarti ada pengaruh yang positif dan signifikan antara brand trust (X3) dengan keputusan pembelian (Y). 
Buying Decision and COVID 19

Pandemic

130

\author{
Pengaruh Kualitas Pelayanan, Fasilitas, dan Brand Trust terhadap Keputusan \\ Pembelian
}

Berdasarkan hasil Uji Simultan (Uji F) diperoleh nilai F hitung sebesar 1022,071 yang lebih besar dari $F$ tabel sebesar 6,238. Oleh dari itu, hipotesis pertama diterima karena kualitas pelayanan (X1), fasilitas (X2), brand trust X3) secara bersama-sama merupakan penjelasan yang signifikan terhadap variabel terkait karena $\mathrm{H} 0$ ditolak dan $\mathrm{H} 1$ diterima. Perolehan nilai $\mathrm{R}$ square sebesar 0,147 membuktikan bahwa variabel-variabel independend (kualitas pelayanan,fasilitas dan brand trust) memiliki kemampuan sebesar $14,7 \%$ dalam menjelaskan variabel variabel dependen (keputusan pembelian). Sedangkan untuk sisanya yang sebesar $85,3 \%$ merupakan variabel-variabel independen lain yang tidak diteliti

\section{PENUTUP}

Beberapa simpulan yang dapat ditarik dari pembahasan tersebut adalah sebagai berikut :

1. Hasil analisis diperoleh bahwa variable kualitas pelayanan (X1) berpengaruh positif dan signifikan pada taraf $10 \%$ terhadap keputusan pembelian (Y) dapat diterima. Hasil nilai thitung sebesar 1,411. dan Signifikansi sebesar 0,164

2. Hasil analisis diperoleh bahwa variabel Fasilitas (X2) berpengaruh positif dan signifikan terhadap keputusan pembelian (Y). Hasil nilai thitung sebesar 1,397 dan signifikansi sebesar 0,165 .

3. Hasil analisis diperoleh bahwa variabel brand trust(X3) berpengaruh positif terhadap keputusan pembelian (Y) maka dapat diterima. Hasil thitung sebesar 2,565 dan signifikansinya 0,012 .

4. Hasil analisis diperoleh bahwa variabel kualitas pelayanan (X1), fasilitas (X2), brand trust (X3) secara bersama-sama mempunyai pengaruh yang positif dan signifikan terhadap keputusan pembelian $(\mathrm{Y})$ dapat diterima.

\section{DAFTAR PUSTAKA}

[1] Kertajaya, H. (2009). New wave marketing, the world is still roundthe market is already flat. Gramedia. Jakarta.

[2] Kotler,Philip (2012). Manajemen pemasaran, edisi ke 14. Alih bahasa Bob Sabran. Erlangga Jakarta.

[3] Mulyana, M. (2012). Consumer Behaviour: Sukses Dengan Memahami Konsumen.

[4] Mulyana, M., Hakim, D. B., \& Hartoyo, S. (2020). Entrepreneurial Activities And Performance Of Rice Farming In Bojongpicung Sub-District, Cianjur Regency. European Journal of Molecular \& Clinical Medicine, 7(3), 4528-4535.

[5] Nurendah, Y., \& Mulyana, M. (2013). Analisis Pengaruh Kualitas Pelayanan Perpustakaan Terhadap Kepuasan dan Hubungannya dengan Loyalitas Mahasiswa. Jurnal Ilmiah Manajemen Kesatuan, 1(1), 93-112.

[6] Purba, J. H. V., Ratodi, M., Mulyana, M., Wahyoedi, S., Andriana, R., Shankar, K., \& Nguyen, P. T. (2019). Prediction Model in Medical Science and Health Care. International Journal of Engineering and Advanced Technology, 8, 815-818.

[7] Sampara,Lukman (1999). Manajemen Kulitas Pelayanan. Alih bahasa Sinambela. STIA- LAN Press. Satori Jakarta.

[8] Tjiptono, Fandy (2014) Pemasaran jasa, prinsip, penerapan \& penelitian. Andi. Yogyakarta. 